\title{
CYCLIC BEHAVIOUR OF EXTERIOR REINFORCED CONCRETE
}

\author{
BEAM-COLUMN JOINTS
}

\author{
L. M. Megget*
}

\begin{abstract}
$\underline{\text { ABSTRACT }}$
This paper is concerned with the experimental behaviour of beam-column joints of reinforced concrete frames with low axial load when subjected to high intensity cyclic loading such as occurs during major earthquakes.

An experimental program was conducted to investigate the behaviour of the external joints of two storey buildings. The parameter varied was the effect on the joint of the addition of transverse beam stubs. The amount of transverse hooping, as specified by the present design code was unchanged for units with and without transverse beams. Both units were subjected to the same program of static cyclic loading and the experimental moment-curvature characteristics are compared.

The unit with transverse intersecting beams formed a plastic hinge in the main beam while the unit without intersecting beams failed within the joint region.
\end{abstract}

\section{REVIEW OF PREVIOUS WORK}

Up to the present time there has been relatively few experimental tests of fullsized reinforced concrete joints under seismic load conditions. The Portland Cement Association has conducted a series of tests $(1,2,3,4)$ on beam-column joints taken from multi-storey frame structures. The beam section ductilities in the critical hinge region reached in these tests were only about five in each direction. (Section ductility is the ratio of maximum curvature to first yield curvature). Park (5) has shown theoretically that section ductilities of plastic hinges of at least 15 are required in a structure which forms a beam-sway mechanism and for which a displacement ductility factor, $\mu$ (maximum displacement/ first yield displacement) of 4 is required. $A$ value of between 4 and 6 was suggested by Blume et al. (6) if a structure is to survive an earthquake of magnitude similar to that of El-Centro. Also in the P.C.A. tests the axial load in the columns was high and the beam shear near the column was lower than the actual conditions due to the length of beam used and the method of load application. The P.C.A. concluded that well detailed joints can resist severe earthquake motions without a loss in strength. However, the simulated earthquake loading program used was not intense enough to really test the joint region under high reversals of shear.

In Japan there have been several fullscale tests of reinforced concrete internal beam-column joints conducted recently. In a summary of tests done at Tokyo University under the supervision of Umemura, Aoyama and Ito (7), the effect the shear reinforcement in the joint zone

* Engineer, New Zealand Ministry of Works, Wellington. had on the strength and stiffness was studied. They found that if the ultimate shear strain was assumed to be $0.4 \%$, the shear stress-joint distortion relationship could be approximated by the method proposed by Endo (8) and others. Higashi and ohwada (9) have tested 17 internal beamcolumn joints with varying forms of anchorage, transverse reinforcement, types of concrete and with and without intersecting transverse beams. 8 of the specimens failed due to shear cracking in the joint and the load carried by these specimens decreased under reversal of loading. The strength and stiffness of the units tested with transverse beams was better than that of similar units without intersecting beams. Since the 1968 Tokachi-oki Earthquake the majority of experimental tests completed in Japan have been on full-sized and scale model columns under simulated earthquake loadings.

Work by Hisada (10) and others on columns and joints is continuing.

The author and Park (1I) conducted tests of 3 full-sized external beam-column joints taken directly from a 2-storey reinforced concrete building. Three further tests were conducted by Smith (12). These tests varied in the method of beam bar anchorage and the amounts and form of transverse reinforcing provided in the joint. All six units failed in the joint region due to severe disruption of the core concrete and loss of anchorage of the beam reinforcing. This paper describes the experimental testing of two further beamcolumn units in the above mentioned series of tests. Renton (13) tested four fullsized external beam-column joints of a multi-storey structure in which the beam was designed to be stronger than the columns. No transverse beams were provided. All 4 units failed in the joint under the high reversals of shear before the theoretical ultimate strength of the column could be 
attained. The continuous U-beam bar detail did not provide enough anchorage in the column and intensive slipping occurred. The integrity of the joint could not be maintained even when more joint hoops were provided than specified by the code. Patton (14) continued this test series with three units to which an anchorage block at the back of the column was provided to anchor the beam bars. Failure still occurred in the joint but performance was improved. Park and Paulay (18), summarise these beam-column tests completed at Canterbury University.

Samerville and Tayler (15) have tested scale model reinforced plaster beamcolumn joints under monotonic loading. They found that the yielding of the beam bars first occurred at a position within the joint, not at the beam-column junction.

\section{DESIGN OF PROTOTYPE}

The prototype structure was designed incorporating the New Zealand Basic Design Loads Code (21), the code of Practice for Reinforced Concrete design (16) and the provisions given in the MOW Design of Public Buildings code (19) for Concrete Ductile Moment-Resisting Space Frames.

The prototype structure was identical to that of the author's previous work (11), viz. a 2-storey reinforced concrete framed Public Building, situated in seismic zone $A$ on firm ground. It was a singlebay frame spanning 20 feet $(6.10 \mathrm{~m})$, with inter-storey heights of 10 feet $(3.05 \mathrm{~m})$. Identical frames were spaced at 15 feet $(4.57 \mathrm{~m})$ centres. The design live loads were $201 \mathrm{~b} / \mathrm{ft}^{2}\left(98 \mathrm{~kg} / \mathrm{m}^{2}\right)$ and $80 \mathrm{lb} / \mathrm{ft}^{2}$ $\left(392 \mathrm{~kg} / \mathrm{m}^{2}\right)$ for roof and lst floor respectively. The dead load of the light timber and steel roof was taken as $40 \mathrm{lb} / \mathrm{ft}^{2}$

$\left(196 \mathrm{~kg} / \mathrm{m}^{2}\right)$. In the structures longitudinal direction small spandrel beams were assumed and precast lightweight concrete panels made up the outer walls.

The basic seismic coefficient from reference (2l) to calculate the code static lateral loads was 0.16 (for natural periods less than $0.42 \mathrm{sec}$ ). The seismic live loads were taken as one third of the full live load at both roof and first floor levels. Static computer analyses using gross section properties were done to find the moments, shears, etc. The design actions were found from the 3 following load combinations: 1.4 Dead + 1.7 live, 1.05 Dead +1.27 Live seismic +1.25 earthquake and 0.9 Dead +1.25 earthquake. Glogau (20) explains the objectives behind the new draft, NZ Seismic Design Code. The design would not change using the proposed seismic coefficients.

The value for Young's modulus $\rho^{f}$ concrete was taken as $3 \times 10^{6} \mathrm{lb} / \mathrm{in}^{2}$ which is considered a little low but is commonly used in Japanese analysis. These actions were checked using the moment distribution method and Muto's (22) approximate method of lateral load analysis. The material properties (minimum) used in the design were all reinforcement yield stress $f_{y}=$ $40 \mathrm{ksi}$ and concrete compressive stress, $\mathrm{f}^{\prime} \mathrm{c}=4 \mathrm{ksi}$.
The restrictions on beam, column dimensions and reinforcement ratios can be found in ref (3).

A "Strong column - weak beam" approach is specified by the code (19) viz. the total ultimate moment capacity of the columns at the design earthquake axial load, should be greater than the total ultimate moment capacity (UMC) of the beams, at any beam-column connection. The ultimate moment capacity for beams in this context means the ACI (17) ultimate moment obtained by using the actual yield stress of the reinforcing and neglecting any increase in capacity due to strain-hardening of the reinforcing and including the capacity reduction factor, $\phi=1$. However, the UMC for columns means the ACI moment capacity calculated using the minimum specified yield stress of the reinforcing and a $\phi$-factor of 0.7 . This process allows the plastic hinges to form first in the beams while the columns remain theoretically elastic, except for hinges forming at the bases of the ground floor columns. Park (5) has shown the importance of a beam-hinge mechanism forming rather than a column-hinge mechanism which requires very high and usually unavailable column rotation ductilities. Armstrong (25) describes in detail the capacity design approach for ductile reinforced concrete frames.

\subsection{Dimensions and Reinforcement}

Prototype Roof Beam: 12 in $(30.5 \mathrm{~cm})$ deep and 10 in $(25.5 \mathrm{~cm})$ wide with 3 No. 6 top bars at ends of beam and bottom mid-span $(p=1.39 \%) .2$ No. 6 bottom bars at the ends and also top bars at mid-span ( $p^{\prime}=$ $0.93 \%)$. Stirrup-ties; $3 \phi$ at 2 inch $(5 \mathrm{~cm})$ centres over 24 inches from face of column. Mid-span; $3 \phi$ stirrups at $d / 2=$ 4 inch centres.

First Floor: 18 inch $(46 \mathrm{~cm})$ deep and 10 inch $(25.5 \mathrm{~cm})$ wide. 2 No. 8 and 1 No. 9 at top ends of beam $(p=1.66 \%)$ and 2 No. 9 bottom $\left(p^{\prime}=1.29 \%\right)$. At mid-span 3 No. 8 bottom ( $p=1.948)$ and 2 No. 8 top $\left(p^{\prime}=1.01 \%\right)$. $3 \phi$ stirrup-ties at 3 inch $(7.6 \mathrm{~cm})$ centres at beam ends. At mid-span $3 \phi$ stirrups at 6 in $(15 \mathrm{~cm})$ centres were required.

Column: 15 inch $(38 \mathrm{~cm})$ deep by 13 in $(33 \mathrm{~cm})$ wide. Main reinforcement was 8 No. 7 bars, 3 in each face $\left(p_{t}=2.95 \%\right)$. At column midheight $3 \phi$ hoops at 4 in $(10 \mathrm{~cm})$ centres were detailed. Special transverse confining reinforcement required was $4 \phi$ closed hoops and supplementary confining ties which pass around both the outer hoop and the longitudinal reinforcing. A spacing of 2 inches $(5 \mathrm{~cm})$ was specified for hoops and confining ties. If hoop steel with a yield stress of 60ksi was available no supplementary confining ties would be necessary.

Joint: $4 \phi$ closed hoops at 2 inch centres were required to carry all the joint shear. However, the same special confining steel specified at column ends is also necessary throughout the joint region. This amount could be halved if beams framed into all 4 sides of the column but this case does not exist in the prototype. 
The horizontal length of beam bar anchorage from the column face to the beginning of the 90-degree bend near the back of the column was assumed to be ineffective as anchorage during reversals of load.

Test specimens: The full-sized unit was taken directly from the prototype design and consisted of the first floor beamcolumn joint, the sections of column to the approximate contraflexure points above and below the joint and a section of the beam. The 7 inch $(17.8 \mathrm{~cm})$ reinforced concrete slab was not included. The length of beam was chosen so that when the negative yield moment was reached at the column face the unit's beam shear at that position would be approximately equal to the actual structure's shear when negative yielding in the beam occurred. Both units $A$ and $B$ had the same principal and transverse reinforcement as the designed prototype. Equivalent metric sizes (soft conversion) were incorporated throughout, refer to Figs $I$ and 2. Unit $A$ had no transverse beams while Unit $B$ had 15 inch $(38 \mathrm{~cm})$ deep by 10 inch $(26 \mathrm{~cm})$ wide transverse beam stubs added to the beam-column joint. 2 No. 7 (D22) top and bottom bars and $3 \phi(9 \mathrm{~mm})$ stirrups at 4 inch ( $10 \mathrm{~cm}$ ) centres were included. Note that $9 \mathrm{~mm}$ diam. supplementary confining ties were used in the units because of restrictions in radius of bend of the $13 \mathrm{~mm}$ bars.

\section{MATERIALS}

Both units were poured at the same time from the same batch of premix concrete, delivered by agitator truck. Normal Portland Cement was used and Table 1 gives the concrete material properties and amounts of each. Specified strength was $270 \mathrm{~kg} / \mathrm{cm}^{2}$ $\left(3,8401 \mathrm{~b} / \mathrm{in}^{2}\right)$ at 28 days.

$6 / 15 \mathrm{~cm}$ long by $5 \mathrm{~cm}$ diameter cylinders were compression tested to find the actual compressive strength. Also $6 / 30 \mathrm{~cm}$ long by $10 \mathrm{~cm}$ diameter cylinders were tested to ascertain the splitting strength of the concrete. Table 1 contains the results of these tests which were done inmediately after completing the main tests, age 40 days.

The mild steel reinforcing used for the principal bars was specified as SD 30 grade (deformed bar with minimum specified yield stress of $\left.3,000 \mathrm{~kg} / \mathrm{cm}^{2}\right), S R 24$ grade mild steel was used for the transverse reinforcing (round bar with minimum yield stress of $2,400 \mathrm{~kg} / \mathrm{cm}^{2}$ ). 3 tensile tests were completed on each size of bar. An electric resistance strain gauge (E.R.S.G.) was glued to each test specimen to obtain the stress-strain characteristics of the reinforcing under monotonically increasing tensile stress. Summary of results of those tests is given in Table 2 .

No facilities were available to test the reinforcing steel under compressive or reversals of loading. It was assumed that the reinforcing had the same properties in compression to those under tension.

\section{I Fabrication of Units}

The fabrication of the reinforcing was performed by the Shimizu Construction
Co. All the reinforcing was cold bent. The column bars were welded at their ends to $1 \mathrm{~cm}$ thick steel plates to facilitate positioning. The reinforcing cages were tied together with tie-wire, no welding was employed.

Both beam-columns were poured on their sides rather than in the normal vertical position. The concrete was poured in one batch, vibrated with a spud vibrator and hand trowelled. The units were dry cured within the enclosed pre-casting building and the moulds were stripped 1 week after pouring.

\subsection{Instrumentation}

Measurements were made of applied load, beam and column deflections, beam hinge rotations, joint distortion, reinforcing strains of beam bars, beam and joint hoops and concrete strains at the beam top and bottom faces. Fig. 3 shows the positions of the dial gauges $(0.0001 \mathrm{~mm}$ and $0.001 \mathrm{~mm}$ accuracy). Detailed description of electric strain gauge positions (type T.M.L. WFLA-6-1I on deformed bars and FLA-3-11 gauges on round bars) are given by the author (27). A continuous record of applied load versus beam deflection was produced by an $X-Y$ plotter using a load cell and a Linear Voltage Displacement Transducer at the point where the load was applied.

The hinge rotation frames were attached to $9 \mathrm{~mm}$ diam. rods welded directly to the outer beam reinforcement. These rods were coated with wax so that the cover concrete did not bond to them. The dial gauge rotations between the $d / 2$ frame and the column face include the slip of the reinforcement either within the joint or the beam.

\subsection{Test Loading}

A low axial column compression of 20 ton was applied throughout with a 50 ton jack. The beam was loaded in both directions by 20 ton hydraulic jacks with a maximum extension of $15 \mathrm{~cm}$.

Slow rates of loading were used to test the specimens and as the main purpose of the tests was to check the joint behaviour and not that of the beam, slowly increasing reversals were used as the earthquake representation. Fig. 4 shows the loading cycle programme used. In cycles 2 and 3 the moment reached in each direction was the first yield moment of the beam near the column face.

A permissible storey drift $(\delta / h)$ of 0.03 is suggested by Krawinkler et al (23). At storey drifts greater than this the chances of local and overall instability occurring within the structure are increasingly possible. Also the small increase in energy capacity does not justify the use of higher storey drifts. A beam deflection of about $5 \mathrm{~cm}$ is equivalent to a storey drift of 0.03 in the prototype. Hence the beam displacements of cycles 10 onwards represent storey drift higher than are at present expected in a well designed structure during a major $E Q$. In most beam-column joints tested in Japan (e.g., refs 9,7 and 24) 
the maximum storey drifts reached were in the range 0.01 to 0.015 . A monotonically increasing load would be much more critical for the beam as the beam would fail probably either due to shear or to buckling of the compression reinforcement. However, increasing load reversals are critical in the joint due to the high joint shear reversals and possible anchorage loss of the beam reinforcement.

\section{TEST RESULTS}

\section{$4.1 \frac{\text { Experimental and Theoretical Yield }}{\text { Moments }}$}

Table 3 gives the theoretical first yield moment capacities of the beam in both directions for UNITS $A$ and $B$. The moments were calculated using the actual material properties given in Tables 1 and 2 and the actual positions of the reinforcing. The first yield moments during testing (increments 19 and 27 , cycle 2) calculated at the beam-column junction are also included as are the ratios of the experimental moment at the peak increment of each inelastic load cycle to the corresponding first yield moment. Note that from the strain gauge results first yielding of the beam reinforcing actually occurred up to $5 \mathrm{~cm}$ within the joint region. If the experimental moment was calculated at a position $5 \mathrm{~cm}$ within the joint the $M$ (first yield) for downward load to My ratio would be 1.01 and not 0.98 as shown.

Unit $A$

\subsection{Load-Deflection}

Fig. 5 shows the applied load-beam deflection plot obtained from the load cell and L.V.D.T. during the test. Cycle 1 is non-linear due to cracking of the beam concrete at the beam-column junction at Inc. 2 and further beam cracking at following increments. The beam-column junction crack and 2 others under upward load had joined the corresponding downward load crack at Inc. 10. In cycle 2, at Inc. 19, the top beam reinforcement yielded. First yield was obvious from the load-deflection plot and the strain gauge readings. The first yield beam displacement was $1.8 \mathrm{~cm}$. First yield in the downward direction occurred between Inc. 26 and 27 . To reach the same load (16 ton) in cycle 3 required a displacement of $3.0 \mathrm{~cm}$. The main reason for this was the non-linear stress-strain behaviour of the reinforcing after yielding in the 2nd cycle had occurred known as the Bauschinger Effect. A higher strain and thus a greater deflection was required in the top reinforcement to produce the yield stress near the beam-column junction.

In cycles 6 and 7 deflections of $4 \mathrm{~cm}$ were reached twice in each direction. Good repeatability was obtained, the moments reached in cycle 7 being only slightly less than those of cycle 6 . During cycle 8 and $9,5 \mathrm{~cm}$ deflections $(\delta / \mathrm{h}=0.03)$ of the beam were reached. At Inc. 84 a moment $6 \%$ and $8 \%$ greater than the theoretical first yield moments were obtained in the down and upward directions respectively due to the main beam rein- forcing strain-hardening. The unit was now very flexible at low loads due to the wide full depth cracking and slipping of reinforcing. However, as the load increased the stiffness increased with the cracks closing to a stiffness similar to those of previous cycles. Note that at the first yield deflection $(1.8 \mathrm{~cm})$ in cycle 8 the moment carried was only $44 \%$ of the first yield moment.

The maximum downward load reached in cycle 9 was $15 \%$ lower than the corresponding load of cycle 8. The Bauschinger effect and also a large increase in the joint distortion were the reasons.

At beam displacements of $6 \mathrm{~cm}$, in each direction during cycle 10, strengths greater than the first yield strength were able to be reached. However, in cycle 11 under downward load a moment of only $77 \%$ of the My value was all that could be obtained at a deflection of $6 \mathrm{~cm}$. Disruption of the joint was severe at this stage. Again under upward load the unit showed good repeatability, cycle 10 and 11 loaddeflection curves were almost identical.

\subsection{Beam Rotations}

First yielding occurred between the beam-column face and a distance $d / 2$ along the beam between increments 18 and 19 . A curvature ductility of 3.0 was reached at Inc. 35 , cycle 3 and this was only slightly exceeded in the following cycles. Thus a plastic hinge formed in the lst and 2nd inelastic cycles but the plastic rotations did not increase as expected in the following cycles. The yielding zone spread along the beam and yielding occurred over the $d / 2$ to d distance in cycle 3 . Again only minor increases in rotation were recorded over this distance in later cycles.

\subsection{Joint Distortion}

Fig. 6 is a plot of the applied load versus the joint distortion rotations. The first joint crack occurred between increments 4 and 5 and the joint appeared to "yield" between Incs. 18 and 19 cycle 2. The joint rotations were less during upward load cycles, the main reason being the smaller loads (80\%) applied in that direction. After cycle 5 there was a general increase in the joint rotations during both directions of loading, although the increase was much larger in downward load cycles. During cycle 10 there was a $50 \%$ increase in the joint rotation over that reached in cycle 9 in both loading directions. A large joint rotation of over 0.03 radians was reached in cycle 12 under downward load. It can be seen from Fig. 6 that the joint region became progressively more flexible and that the amount of energy being dissipated was small when compared with the large rotations reached in the later cycles.

\subsection{Components of Inelastic Rotations}

In Fig. 7 the beam hinge rotations from beam-column to $d / 2$ (no slip) and $d / 2$ to $d$ are plotted together with the joint distortion rotations at the peaks of each downward load cycle. It is clear that there was very little increase in the beam plastic 
hinge rotations after cycle 3 while the joint distortion rotations continue to increase at an almost linear rate. Also the beam hinge rotation from $d / 2$ to $d$ (cycle 3 onwards) was approximately half of the rotation from near the beam-column to a section $d / 2$ along the beam. Note that in cycle 3 only $32 \%$ of the inelastic rotation was due to joint distortion but by cycle 8 and cycle 10 this has become $49 \%$ and $61 \%$ respectively.

\subsection{Joint Hoop Stresses}

Fig. 8 gives some idea of the distribution of hoop stresses down the joint at downward cycle peaks. As the strains were only recorded in 3 of the 6 hoops between the beam bars, only an approximate stress distribution can be given. Generally the stresses increased-gradually cycle after cycle with the highest stresses being recorded during cycle 10. There was a decrease in the hoop stresses in cycle 11 as the applied load was less for an equal beam deflection as in the previous cycle. The stresses were generally less at the back of the joint region away from the beam. Stresses were also less for the hoops near the beam bars when compared to the mid-joint hoop. The stresses were smaller in the hoops during upward load cycles when compared with the corresponding downward load cycle. The smaller applied load (upward) would be the main reason. Note that the first yielding of the mid and bottom joint hoops during cycle 10 corresponds with the 50\% increase in joint distortion measured between cycles 9 and 10, refer to Fig. 6.

\subsection{Formation of Cracks}

The formation of cracks were checked at each cycle peak and were drawn on the unit and photographed. Fig. 9 shows the chronological formation of cracks at cycles 6, 10 and 13 for downward directions of loading. Fig. 10 shows a scale drawing of cracks in the joint region after lst yielding had been reached in both directions.

Note the $20^{\circ}$ to vertical crack down the joint which formed under downward loading. The 2 diagonal cracks across the joint in the other direction are steeper at $40^{\circ}$ to the vertical. The diagonal cracks do not form at $45^{\circ}$ which is assumed in the theory but rather they form from one corner to the opposite diagonal corner. Smith (12) concluded the same thing. These diagonal cracks gradually increased in length and more intermediate ones formed in the following cycles.

In cycle 5 the main diagonal crack was about $1 \mathrm{~mm}$ wide increasing to $2 \mathrm{~mm}$ wide in cycle 6 at the centre of the joint and the joint cover concrete on the back of the column was splitting outwards. It was obvious in cycle 8 that the joint cover concrete was bulging outwards at the joint centre. By cycle 10 there were 4 cracks diagonally across the joint, which were at about $5 \mathrm{~cm}$ centres. The cover concrete was very loose and could be removed by hand.

The beam compression cover concrete had also spalled and the beam-column junction crack was about lcm wide by cycle 12. All the other beam cracks (4 main ones) were less than $1 \mathrm{~mm}$ wide when the joint diagonal cracks were about $5 \mathrm{~mm}$ wide. The inelastic rotations moved from the beam to the joint as the joint became more and more disrupted. This was seen from the $d / 4$ and $d / 2$ beam cracks which were about $2 \mathrm{~mm}$ wide in cycle 6 but were only half as wide in later cycles.

\section{Unit $B$}

\subsection{Load-Deflection}

Fig. Il shows the applied lateral load versus beam deflection plot obtained from the $X-Y$ plotter. Note the good repeatability of cycles 6 and 7,8 and 9 and the reasonable repeatability of cycles 10 and 11 for both loading directions. During cycle 12 there was distinct drop in applied load able to be carried at a certain deflection compared with previous cycles. There was a $26 \%$ decrease in experimental to yield moment ratio between the peaks of cycles 11 and 12, see Table 3. The load carried at Inc. 138, cycle 13 was $95 \%$ of the first yield moment, this decrease being due to the shear failure of the beam. During upward loading cycles there was very little marked decrease in stiffness from cycle 4 onwards, the loading curves for subsequent cycles were almost identical. The load reached in all cycles after cycle 6 was greater than the first yield load or in other words there was no loss in load carrying capacity under upward loading during repeated load cycles.

\subsection{Beam Rotations}

Under upward load in cycle 3 , a deflection of $4 \mathrm{~cm}$ was reached in an effort to obtain the first yield moment of cycle 2. This resulted in a very large curvature between the column face and $d / 2$ along the beam at Inc. 42. In subsequent upward load cycles this curvature was not exceeded. However, during downward load cycles the beam curvatures increased steadily, the biggest single increase being between cycles 2 and 3 . Before cycle 12 the shape of the cyclic curves (sections $d / 2$ to $d$ ) were similar to those expected from a structural steel beam; there being no large decrease in stiffness with repeated load cycles. The slippage curvatures from beam-column to $d / 2$ section were about 10\% greater than the corresponding no-slip curvatures throughout the test.

\subsection{Joint Distortion}

Fig. 12 is the plot of the applied load versus the joint distortion rotation obtained from the diagonal joint dial

gauges. The joint appeared to crack at an applied load of 12 ton in cycle 1 . The joint rotations show small increases with successive down and up load cycles. However, when compared with the joint distortion of UNIT A(Fig. 6) the increases are much smaller. There was only a minor decrease in joint stiffness throughout the first 11 cycles. In cycle 12 under downward load, there is an obvious decrease in stiffness but the joint rotation at Inc. 
124 is only $25 \%$ of the corresponding joint rotation in UNIT $A$.

\section{Il Components of Inelastic Rotation}

The plastic beam rotations together with the joint rotations are plotted in Fig. 13 for the downward load cycle peaks. The plastic beam rotation from the column face to the $d / 2$ section is the major component in the inelastic rotations while the joint rotations remain almost constant from cycle 3 onwards. This is in direct contrast to the rotation components of UNIT A. All rotation components remain almost constant for the cycles in which the same peak deflection is reached. The increases in rotation occur as the beam is forced to greater deflections as expected.

\subsection{Joint Hoop Stresses}

The mid-joint hoop was very near to yielding in cycle (10). Inc. 105 and in later cycles stable reading were unobtainable. The strains in the hoops increased with each cycle, the strains being less under upward loading due to the smaller applied load in that direction.

Fig. 14 is the approximate stress distribution in the joint hoops at downward load cycle peaks. Note the hoops nearest the beam reinforcing seem less suitable in carrying shear. The stresses plotted are the average of the two gauges on each of the 3 hoops. The stresses in the lower hoop are much less than the mid and top hoops. The maximum stresses recorded in the top and bottom joint hoops were 94\% fy at Inc. 124 and $61 \%$ fy also at Inc. 124 respectively.

\subsection{Beam Bar Stresses}

The beam stirrup nearest the column yielded in cycle 3 , Inc. 35 while the second stirrup first yielded during cycle 5 . Unfortunately after the stirrups had yielded, further stable readings become difficult to obtain due to the beam shear cracks crossing the stirrups where the gauges were positioned. In UNIT A the beam stirrups-ties did not yield, the greatest stress reached being $0.50 \mathrm{fy}$. This seems due to the lack of a beam hinge in UNIT A allowing the shear to be carried by the less disrupted beam concrete.

\subsection{Crack Formation}

Fig. 15 shows the crack pattern at cycle peaks, 10 and 13 and after the test with loose concrete removed. Cracking in the joint region was minor, first cracking into the stub occurred during cycle 2 . The major cracking occurred in the beam; in cycle 2 the beam-column junction cracked widened to $2 \mathrm{~mm}$ while the five other beam cracks were less than $1 \mathrm{~mm}$ wide. In cycle 4 the main crack was $5 \mathrm{~mm}$ wide and the others greater than $1 \mathrm{~mm}$ in width. A beam hinge had obviously formed and no changes of cracking into the joint or stubs were visible. During cycle 6 the beam cracks had extended and turned to approximately 45 degree shear cracks near the opposite face of the beam. Due to the reversals the beam-column concrete was very loose and crushed.
The major shear deformation in the beam occurred at Inc. 105, cycle 10. The main shear crack was $2 \mathrm{~mm}$ wide at midbeam depth and this increased to $6 \mathrm{~mm}$ in cycle li but the crack was only $2 \mathrm{~mm}$ wide at the top face where it was a flexural crack.

There was a noticeable shear deformation in the bottom beam bars and pieces of concrete could be removed from within the stirrup-ties. A splitting crack had formed down the back of the column on one side only, late in the testing.

\section{DISCUSSION}

By comparing the components of inelastic rotation for UNITS $A$ and $B$ it was obvious that after cycle 3 the major plastic rotation occurred in the joint in UNIT A while in UNIT B it occurred in the beam. For example in cycle 10, Inc. 105, $39 \%$ and $74 \%$ of the inelastic rotation was due to plastic beam rotation in UNITS $A$ and $B$ respectively. The load carrying capacities of both units were very similar and the only difference was in the position of the major disruption. The transverse beam stubs of UNIT B had the effect of confining the joint concrete better. In UNIT $A$, once the joint cover concrete had diagonally cracked and split the joint hoops were able to bow slightly outwards under the pressure of the core concrete. This caused the beam bars to slip along their anchorage length and then when the joint hoops yielded major disruption of the internal core concrete occurred. Thus the position of the main inelastic rotation shifted from the beam to the joint region after 2 to 3 inelastic cycles in each direction. In UNIT $B$ the presence of the transverse stub beams prevented the joint cover concrete from splitting outwards and the position of the main plastic rotations remained in the beam.

It is felt that the presence of the transverse beam reinforcing had little effect in confining the joint region. The transverse beam bars were not in contact with the anchorage length of the main beam bars and thus any restraint on them slipping and anchorage loss would have been minimal.

Diagonal joint cracking occurred in both units before first yielding of the beam reinforcement had commenced. The nominal shear stress in the joint at first cracking was $0.15 \mathrm{f}^{\prime} \mathrm{C}$ and $0.17 \mathrm{f}^{\prime} \mathrm{C}$ for UNITS A and B respectively. Higashi (9) gives values of $0.12 f^{\prime} \mathrm{C}$ and $0.15 \mathrm{f}^{\prime} \mathrm{C}$ for beam-column joints without and with transverse stub beams respectively.

The theoretical maximum shear that the 6 hoops positioned between the top and bottom beam reinforcing could carry is 110 kips when all are yielding. (In the test not all the hoops yielded but the hoops immediately above and below the beam bars also carry some joint shear and this is neglected in the above figure.) The ACI code (17) formulae for shear carried by the concrete gives a minimum value of 33 kips for the test (neglecting $\phi$-factor) column. Thus the maximum joint shear able to be carried by the joint was approximately 
143 kips, (Vs + Vc). In UNIT A the maximum joint shear (Asfs - H) at cycle 8 equalled $135 \mathrm{kips}$ and $143 \mathrm{kips}$ for UNIT $\mathrm{B}$ in cycle 11. During reversals of shear the joint hoops must not yield as this causes disruption of the core concrete which then can no longer carry any shear. In previous tests, (references 4, 14, 15 and 17) this conclusion was also clear.

The main conclusion of UNITS $A$ and $B$ is that the presence of transverse beams greatly contributes to the confinement of the joint core concrete and thus allows a ductile plastic hinge to form entirely in the beam rather than a brittle shear dependent hinge in the joint region. How ever, it is uncertain whether this benefit will still exist in the actual case where the transverse beams will have cracked along their beam-column junctions during a non-uni directional earthquake.

Figs. 16 and 17 show the sum of energy dissipation of the beam hinges and the joint distortion for the first downward load cycle at each specified deflection against the beam deflection for UNITS A and $B$ respectively. The energy dissipated in the joint of UNIT A continues to increase during the test while the sum of the plastic beam hinge energy dissipation remains almost constant aftercycle. 3 . The opposite is true in UNIT B where the sum of the beam hinge energy dissipation continues to increase throughout the test. Note also the increasing energy dissipation in the hinge from the $\mathrm{d} / 2$ to $\mathrm{d}$ region. The energy dissipation capacity of a structure is an important factor in describing how the structure will behave during a major earthquake. It can be seen that the joint will dissipate large amounts of energy but a joint "hinge" is undesirable because of its brittle nature, degrading strength and the integrity of the columns is effected. The excellent moment-curvature (strength-ductility) behaviour of well detailed beams under repeated reversals should be used as the energy dissipating component in frame structures.

Fig. 18 shows the ratio of moment reached at each cycle peak to the first yield moment against the beam section ductility reached at each cycle. (Beam section ductilities were measured over a length from the column face to a section approximately $\mathrm{d} / 2$ along the beamb. The author's (26) and Smith's (12) previous tests of identically sized beam-column joints are shown with the present 2 units.

A brief description of the units is given below:

UNIT I had only 3 joint hoops and beam bar anchorage lengths measured from end of 90-degree bend.

UNIT 23 joint hoops with continuous $U$ beam bars.

UNIT 34 joint hoops, normal anchorage length measured from beam-column junction.

UNIT 45 joint hoops, normal anchorage detail.

UNIT 54 joint hoops + internal spiral cage in joint.

UNIT 65 joint hoops + internal rectangular case in joint. Also 3 top bars and
4 bottom bars in beam compared with

2 No. 9 bars top and bottom of UNITS 1 to 5 .

UNIT A 6 joint hoops + supplementary confining ties, 3 top bars and 2 bottom bars in beam.

UNIT B Identical to UNIT A except for addition of transverse beam stubs to joint + reinforcing.

\section{CONCLUSIONS}

1. The addition of transverse stub beams to the beam-column joint caused the major inelastic rotations to occur in the beam rather than in the beam-column joint region. In the other seven units tested in this series, all without transverse beams, the hinge formed in the joint region.

2. Joint hoops were provided to carry all the joint shear but they proved insufficient in the unit without transverse beams. Under repeated reversals of post-yielding load the joint core concrete broke up, thus destroying the integrity of the column.

3. More joint hoops should be provided a mid-depth than at the joint extremities because it seems they are more efficient in carrying shear near the centre of the joint.

4. When reversals of load are expected the joint hoops should not yield and this requires providing more hoops than are necessary to carry all the joint shear.

\section{The supplementary confining ties} provided across the column restrained the joint hoops from bowing outward, but care must be taken in the detailing to ensure tight connections between s.c. ties, main hoops and column bars. Combinations of closed hoops may be better for confining the core concrete on the construction site where experimental conditions do not exist.

6. The horizontal portion of beam bar anchorage length from column face to the 90-degree bend, becomes ineffective as anchorage after one reversal of postyielding load.

\section{ACKNOWLEDGEMENTS}

This investigation was made possible by UNESCO in the form of an advanced course Fellowship to the International Institute of Seismology and Earthquake Engineering, Tokyo, Japan. I acknowledge the assistance given by Professor V. V. Bertero, UNESCO Expert at I.I.S.E.E., Professor H. Umemura, Professor of Architecture, Tokyo University, and the Ministry of Works for a Study Award and practical assistance.

\section{REFERENCES}

(I) Hanson, N. W. and H. W. Connor: Seismic Resistance of Reinforced Concrete Beam-Column Joints, Proc. A.S.C.E., 93, (1967), 533-560.

(2) Corley, G. and N. W. Hanson: Design of Beam-Column Joints for Seismic Resistant Reinforced Concrete Frames, Proc. 4th World Conf. Earthq. Engin., Santiago, (1969).

(3) Hanson, N. W. and H. W. Connor: Seismic Resistance of Reinforced Concrete Beam- 
Column Joints - Further Tests, Report to be published.

(4) Hanson, N. W.: Seismic Resistance of Concrete Frames with Grade 60 Reinforcement, Proc. A.S.C.E., 97, (1971), $1685-1700$.

(5) Park, R.: Ductility of Reinforced Concrete Frames Under Seismic Loading, N.Z. Engineering 23, (1968), 247 435 .

(6) Blume, J.A., N. W. Newmark and L. H. Corning: Design of Multi-Storey Reinforced Concrete Buildings for Earthquake Motions, Portland Cement Association, Illinois, (1961).

(7) Umemura, H., H. Aoyama and M. Ito: Experimental Studies on Reinforced Concrete Members and Composite Steel and Reinforced Concrete Members, University of Tokyo Publication, (December 1970).

(8) Endo, T. and Others: Strength and Stiffness of Reinforced Concrete Connection Panel, Trans. A.I.J., Extra, (1965), 206.

(9) Higashi, Y. and Y. Ohwada: Failing Behaviours of Reinforced Concrete Beam-Column Connection Subjected to Lateral Load, Mem. Fac. Tech., Tokyo Metropolitan Univ., 19, (1969), 91 101.

(10) Hisada, T., N. Ohmuri and S. Bessho: Earthquake Design Considerations in Reinforced Concrete Columns, Kajima Inst. Const. Techno., Rep. No. 1, (1972).

(1I) Megget, L. M. and R. Park: Reinforced Concrete Exterior Beam-Column Joints Under Seismic Loading, N.Z. Engineering, 26, (1971), 341-354.

(12) Smith, B. J.: Exterior Reinforced Concrete Joints with Low Axial Load Under Seismic Loading, Unpublished Master of Engineering Report, Univ. of Canterbury, New Zealand, (1972).

(13) Renton, G. W.: The Behaviour of Reinforced Concrete Beam-Column Joints under Cyclic Loading, Unpublished Master of Engineering Thesis, Univ. of Canterbury, New Zealand, (1972)

(14) Patton, R.N.: Behaviour Under Seismic Loading of Reinforced Concrete BeamColumn Joints with Anchor Blocks, Unpublished Master of Engineering Report, Univ, of Canterbury, New Zealand, (1972).

(15) Somerville, G. and H. P. J. Taylor: The Influence of Reinforcement Detailing on the strength of Concrete Structure, Jour. Inst. Struc. Engin., 50, (1972), $7-19$.

(16) Standards Association of New Zealand: NZS 310P, 1970 Code of Practice for Reinforced Concrete Design, Wellington, (1970).

(17) American Concrete Institute: A.C.I. 318 - 71, Building Code Requirements for Reinforced Concrete, (1971).

(18) Park, R. and Paulay, T.: Behaviour of Reinforced Concrete External Beam-Column Joints Under Cyclic Loading, Proc. 5th World Conf. Earthquake Engineering, Rome, (1973).

(19) Ministry of Works:PW $81 / 10 / 1$ : Design of Public Buildings, Code of Practice. MOW, New Zealand, (1970).

(20) Glogau, 0. A.: The Objective of the New Zealand Seismic Design Code, Bull. N.Z. Society for Earthquake Engineering, Vol. 5, No. 4, December (1972),
$113-127$.

(21) New Zealand Standard Model Building Bylaw, Basic Design Loads. NZSS 1900, Chapter 8, Dec., (1965).

(22) Muto, K.: Seismic Analysis of Reinforced Concrete Buildings, Revised Edition, Tokyo, Shokoku-sha, (1965).

(23) Krawinkler, H., V. V. Bertero and E. P. Popov: Inelastic Behaviour of Steel Beam-to-Column Subassemblages, Earthq. Engin. Res. Centre Rep., 71, Univ. of Calif. Berkeley, (1971).

(24) Ohwada, Y. and Others: Study on Reinforced Concrete Beam-Column Connection subjected to Lateral Loads, Trans. A.I.J., Extra, 337, (1967).

(25) Armstrong, I. C.: Capacity Design of Reinforced Concrete Frames for Ductile Earthquake Performance, Bull. N.Z. Soc. for Earthquake Engineering, Vol. 5, No. 4, Dec., (1972), 133 - 142.

(26) Megget, L.M.: Anchorage of Beam Reinforcement in Seismic Resistant Reinforced Concrete Frames, Unpublished Master of Engin. Rep., Univ. of Canterbury, New Zealand, (1971).

(27) Megget, L.M.: Exterior Reinforced Concrete Joints with and Without Intersecting Beams Under Seismic Loading, Bull. I.I.S.E.E. Vol. 1l, (1973). 
TABLE 1

CONCRETE PROPERTIES

\begin{tabular}{|l|c|c|}
\hline Materials & Fine Aggregate & Coarse Aggregate \\
\hline Maximum Size & $5 \mathrm{~mm}$ & $25 \mathrm{~mm}$ \\
Fineness Modulus & 2.81 & 6.91 \\
Specific Gravity & 2.60 & 2.65 \\
\hline
\end{tabular}

CONCRETE MIX PROPORTIONS

\begin{tabular}{|l|c|c|}
\hline Cement & $373 \mathrm{~kg} / \mathrm{m}^{3}$ & \\
Water & $176 \mathrm{~kg} / \mathrm{m}^{3}$ & \\
Sand & $788 \mathrm{~kg} / \mathrm{m}^{3}$ & \\
Gravel & $1030 \mathrm{~kg} / \mathrm{m}^{3}$ & \\
AE Agent & $130 \mathrm{~g} / \mathrm{m}^{3}$ & \\
Water-Cement Ratio & 468 & \\
Fine Aggregate Ratio & 42.28 & \\
\hline
\end{tabular}

CONCRETE STRENGTH

\begin{tabular}{|l|c|l|}
\hline Compressive & $225 \mathrm{~kg} / \mathrm{cm}^{2}$ & \\
Splitting & $22.8 \mathrm{~kg} / \mathrm{cm}^{2}$ & \\
\hline
\end{tabular}


TABLE 2

REINFORCING STEEL PROPERTIES

\begin{tabular}{|c|c|c|c|c|c|c|c|}
\hline $\begin{array}{c}\text { Reinforcing } \\
\text { Size } \\
\text { (Grade) }\end{array}$ & $\begin{array}{c}\text { Yield } \\
\text { Stress, } \\
\text { fy } \\
t / \mathrm{cm}^{2} \\
\left(k / \mathrm{in}^{2}\right)\end{array}$ & $\begin{array}{c}\text { Tensile } \\
\text { Stress, } \\
\text { fsu }\end{array}$ & $\frac{f s u}{f y}$ & $\begin{array}{l}\text { Youngs' } \\
\text { Modulus, } \\
\text { Es } \\
\left(k / i^{2}\right)\end{array}$ & $\begin{array}{c}\text { Elongation, } \\
\delta \\
8\end{array}$ & $\begin{array}{l}\text { Yield } \\
\text { Strain, } \\
\text { Ey }\end{array}$ & $\begin{array}{c}\text { Strain } \\
\text { Hardening } \\
\text { strain, } \\
\text { (xEy) }\end{array}$ \\
\hline$\frac{D-29}{(\operatorname{SD} 30)}$ & $\begin{array}{l}3.816 \\
(54.27)\end{array}$ & $\begin{array}{l}5.66 \\
(80.55)\end{array}$ & 1.49 & $\left(25 \times 10^{3}\right)$ & 26 & 0.0022 & 10 \\
\hline$\frac{D-25}{(S D 30)}$ & $\begin{array}{l}3.846 \\
(54.7)\end{array}$ & $\begin{array}{l}5.838 \\
(83.0)\end{array}$ & 1.52 & $\left(26.4 \times 10^{3}\right)$ & 19 & 0.0022 & 10 \\
\hline$\frac{D-22}{(S D 30)}$ & $\begin{array}{l}3.72 \\
(53.0)\end{array}$ & $\begin{array}{l}4.17 \\
(59.3)\end{array}$ & 1.12 & $\left(24.5 \times 10^{3}\right)$ & 17 & 0.0021 & \\
\hline$\frac{13 \phi}{(\mathrm{SR24})}$ & $\begin{array}{l}3.23 \\
(46.0)\end{array}$ & $\begin{array}{l}4.51 \\
(64.2)\end{array}$ & 1.40 & $\left(25.9 \times 10^{3}\right)$ & 32.7 & 0.0018 & \\
\hline$\underset{(\mathrm{SR24})}{\stackrel{9 \phi}{=}}$ & $\begin{array}{l}4.09 \\
(58.2)\end{array}$ & $\begin{array}{l}5.27 \\
(74.8)\end{array}$ & 1.29 & $\left(27.2 \times 10^{3}\right)$ & 29 & 0.0021 & \\
\hline
\end{tabular}

TABLE 3

MOMENT DEGRADATION WITH INCREASED LOAD REVERSALS

\begin{tabular}{|c|c|c|c|c|c|c|c|c|c|c|c|c|c|c|c|}
\hline \multirow[t]{2}{*}{ UNIT } & \multirow{2}{*}{$\begin{array}{l}\text { APPLIED } \\
\text { IOAD } \\
\text { DIRN. }\end{array}$} & \multirow{2}{*}{$\begin{array}{l}\text { CALC. } \\
M_{Y} \\
t c m\end{array}$} & \multirow{2}{*}{$\begin{array}{c}\text { TEST } \\
M_{Y} \\
t c m\end{array}$} & \multirow{2}{*}{$\mid \begin{array}{c}M_{y} \text { test } \\
M y \\
\text { Cycle } \\
2\end{array}$} & \multicolumn{11}{|c|}{$\begin{array}{c}\text { Experimental Moment at Cycle Peaks } \\
\text { First Yield Moment }\end{array}$} \\
\hline & & & & & 3 & 4 & 5.7 & 6 & 7 & 8 & 9 & 10 & 11 & 12 & 13 \\
\hline A & $\begin{array}{l}\text { DOWN } \\
\text { UP }\end{array}$ & $\begin{array}{l}2,216 \\
1,724\end{array}$ & $\begin{array}{l}2,240 \\
1,820\end{array}$ & 1.01 & $\begin{array}{l}1.01 \\
1.04\end{array}$ & $\begin{array}{l}0.90 \\
0.99\end{array}$ & $\mid \begin{array}{l}0.82 \\
1.02\end{array}$ & $\begin{array}{l}0.93 \\
1.02\end{array}$ & $\begin{array}{l}0.92 \\
0.99\end{array}$ & $\begin{array}{l}1.06 \\
1.08\end{array}$ & $\begin{array}{l}0.90 \\
1.06\end{array}$ & $\begin{array}{l}1.03 \\
1.08\end{array}$ & $\begin{array}{l}0.77 \\
1.04\end{array}$ & $\begin{array}{l}0.79 \\
1.08\end{array}$ & $\mid \begin{array}{c}1.04 \\
-\end{array}$ \\
\hline B & DOWN & $\begin{array}{l}2,258 \\
1,703\end{array}$ & 1,750 & 0.98 & 1.07 & 0.88 & 0.92 & 1.07 & 1.07 & 1.09 & $\begin{array}{l}1.02 \\
1.13\end{array}$ & $\begin{array}{l}0.99 \\
1.09\end{array}$ & $\begin{array}{l}1.10 \\
1.11\end{array}$ & $\mid \begin{array}{l}0.84 \\
1.15\end{array}$ & 0.95 \\
\hline
\end{tabular}



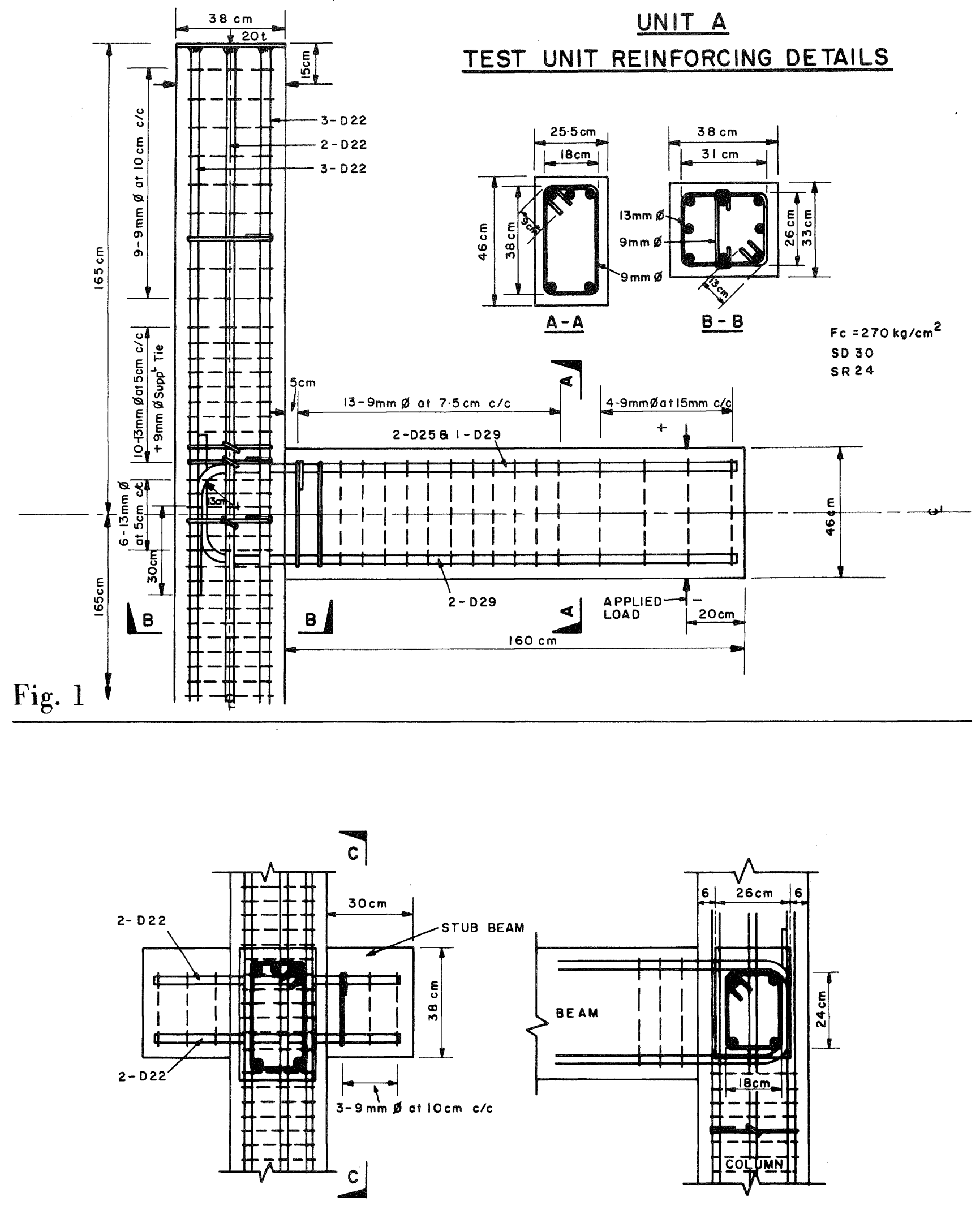

$\underline{\text { UNIT B }}$

Fig. 2 

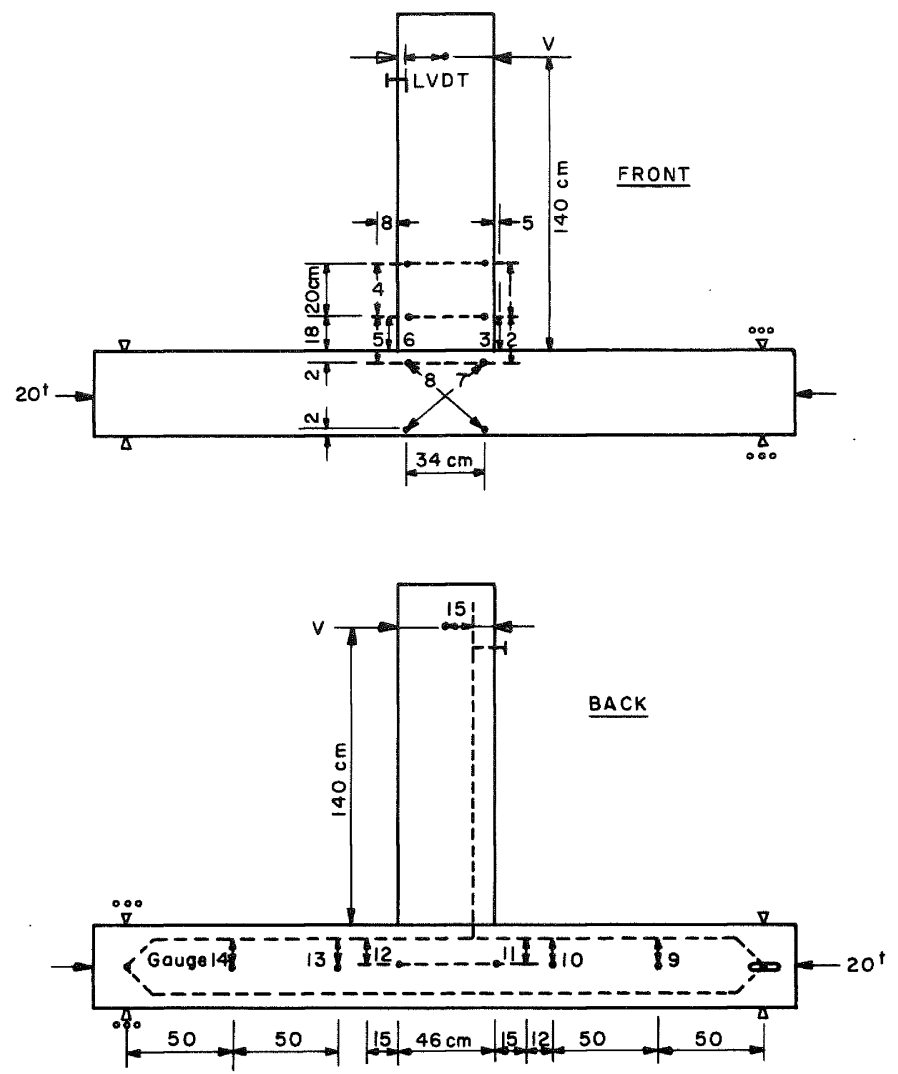

UNITS A \& B

Fig. 3

DIAL GAUGE POSITIONS

(- - - REPRESENTS DIAL GAUGE FRAMES)

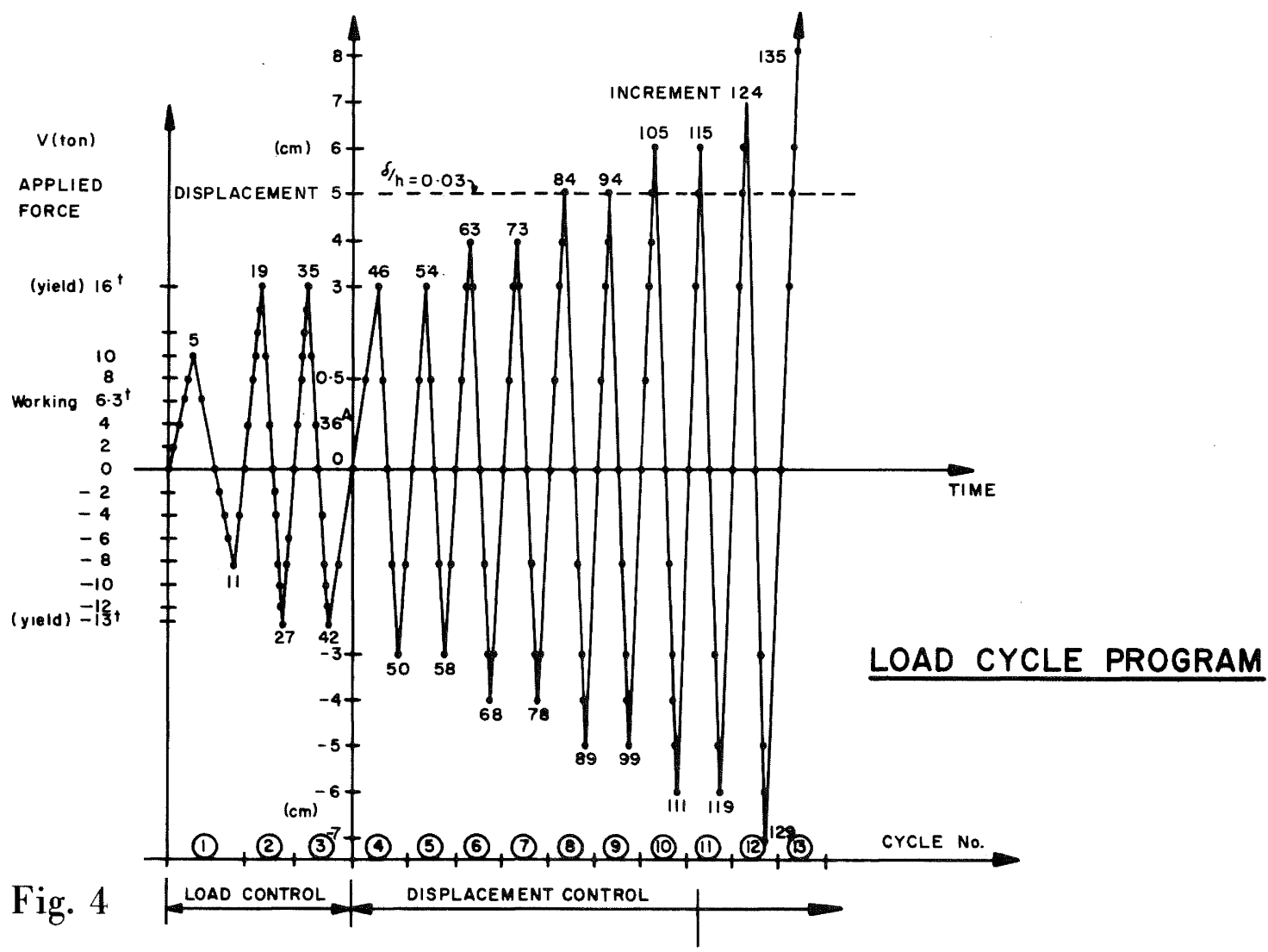



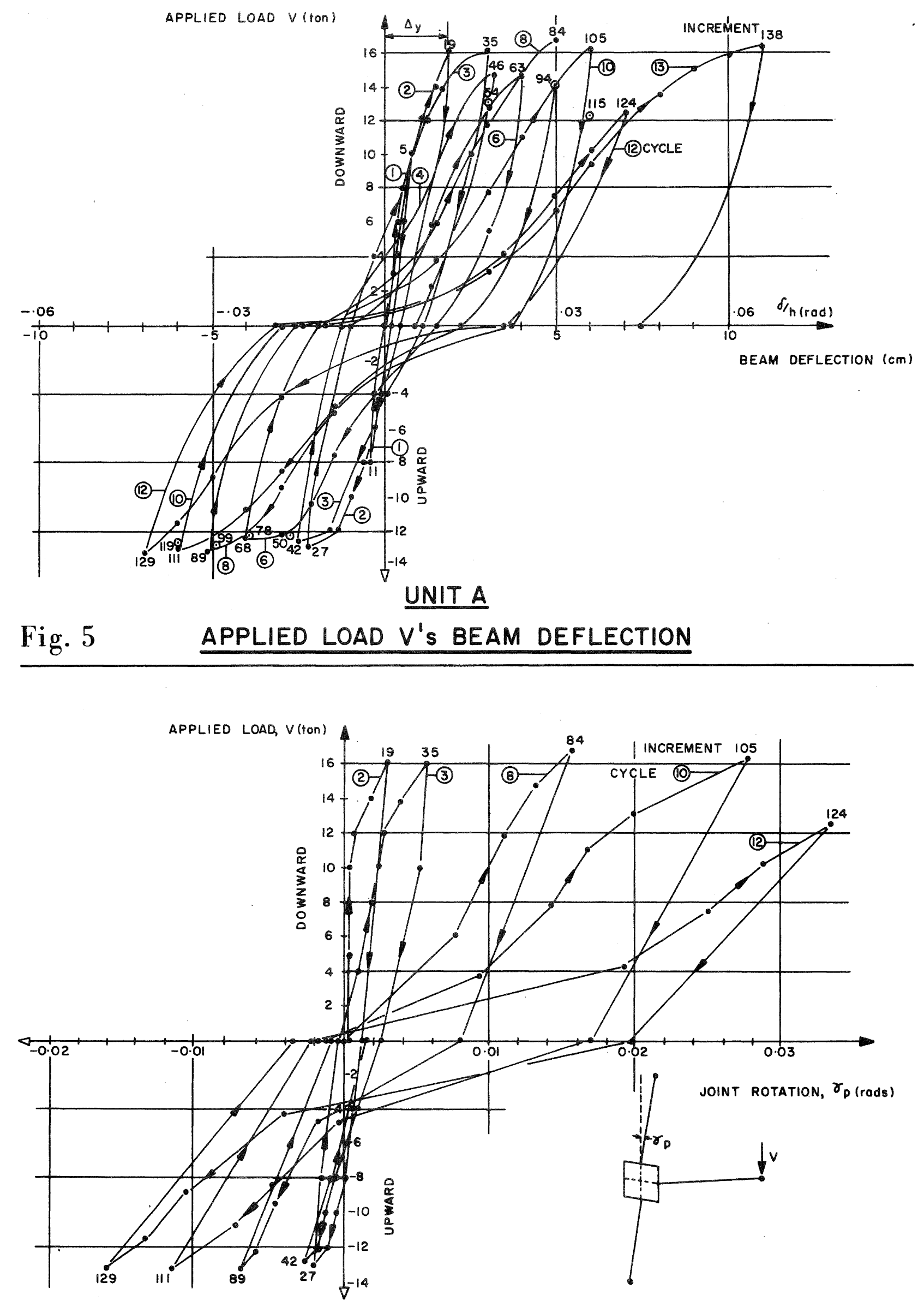

UNIT A

Fig. 6 


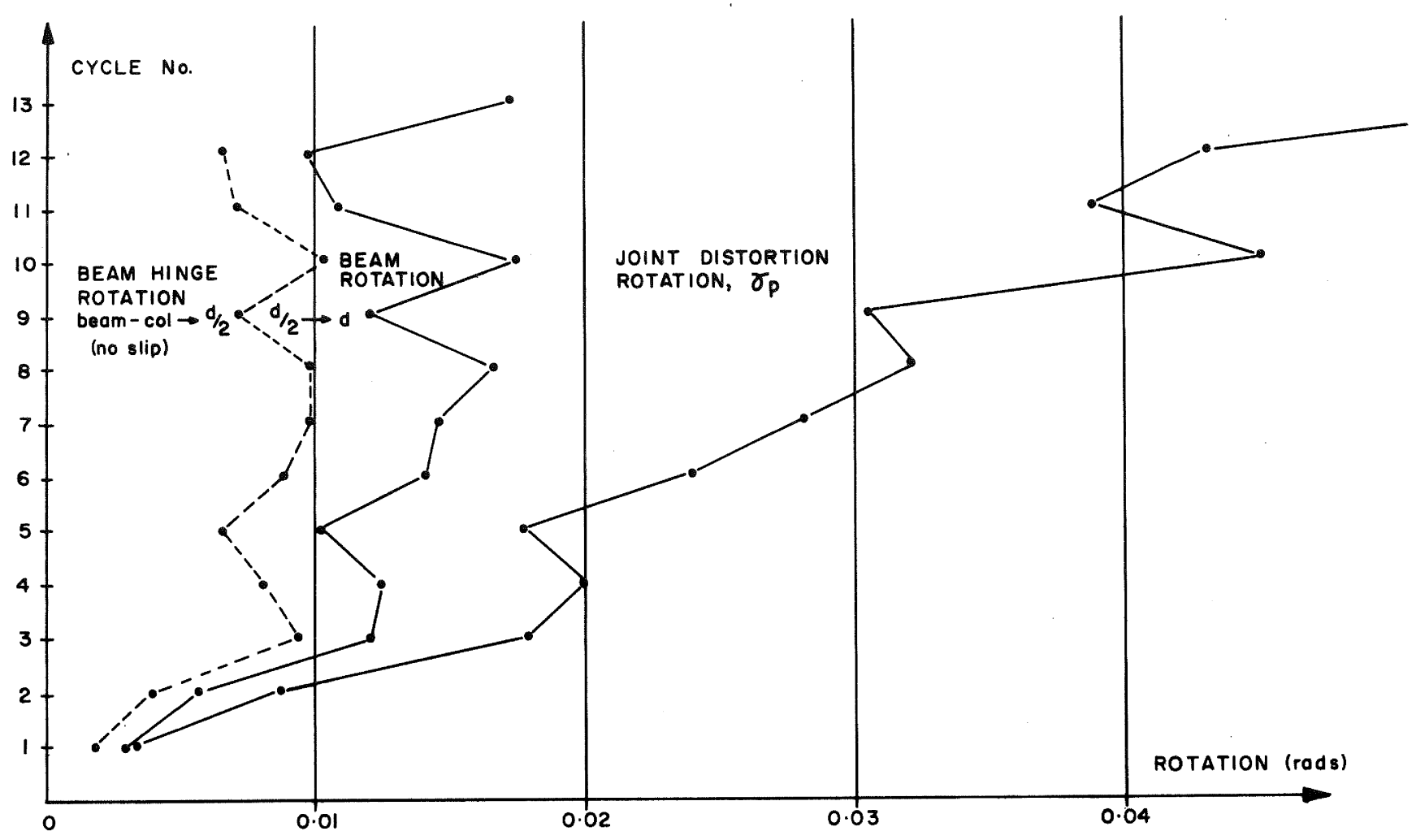

Fig. 7

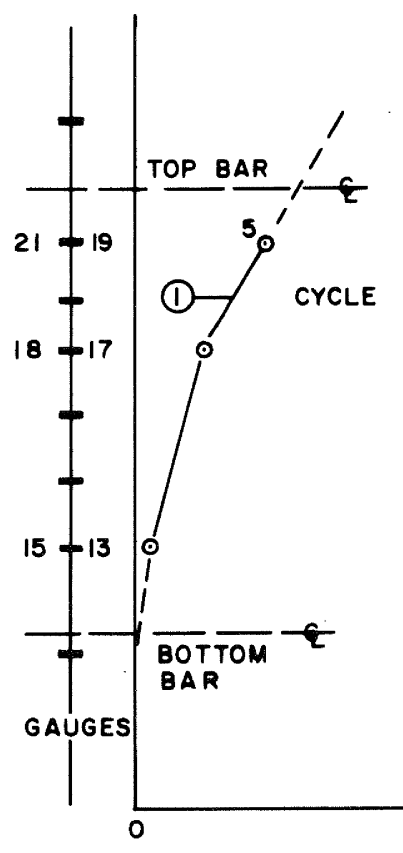

Fig. 8

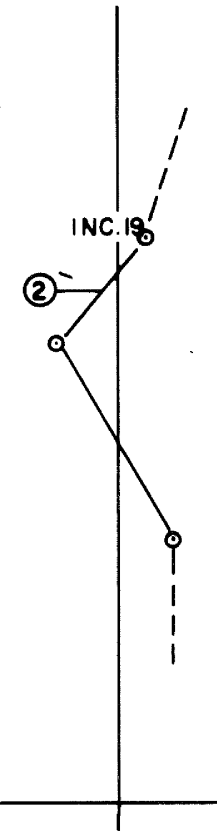

(4)
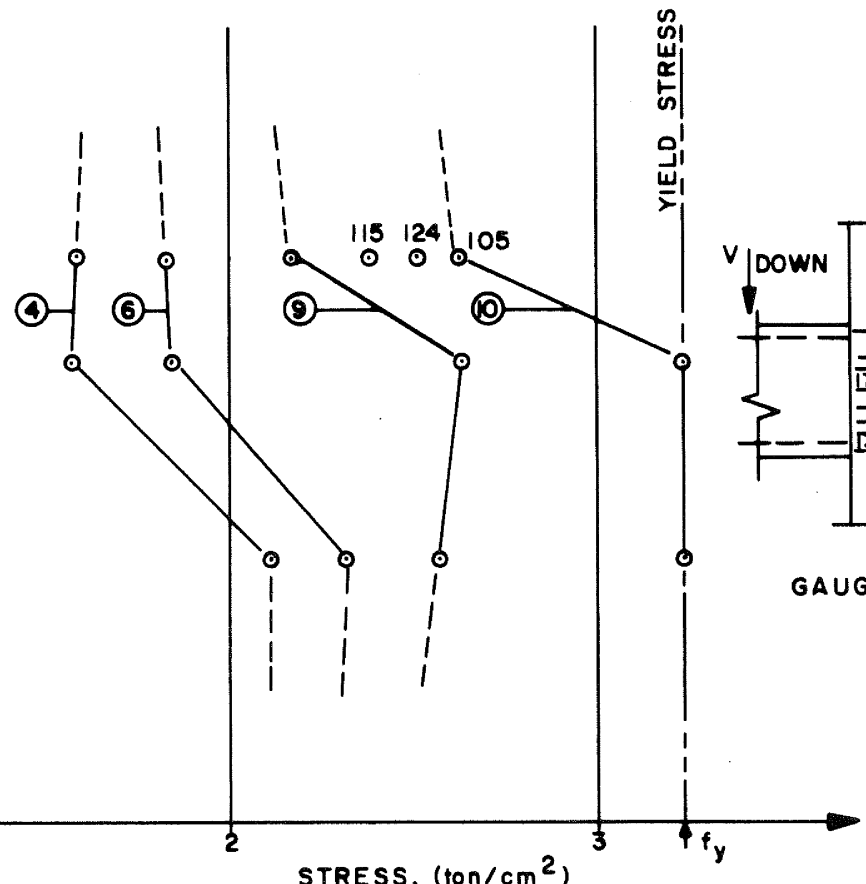

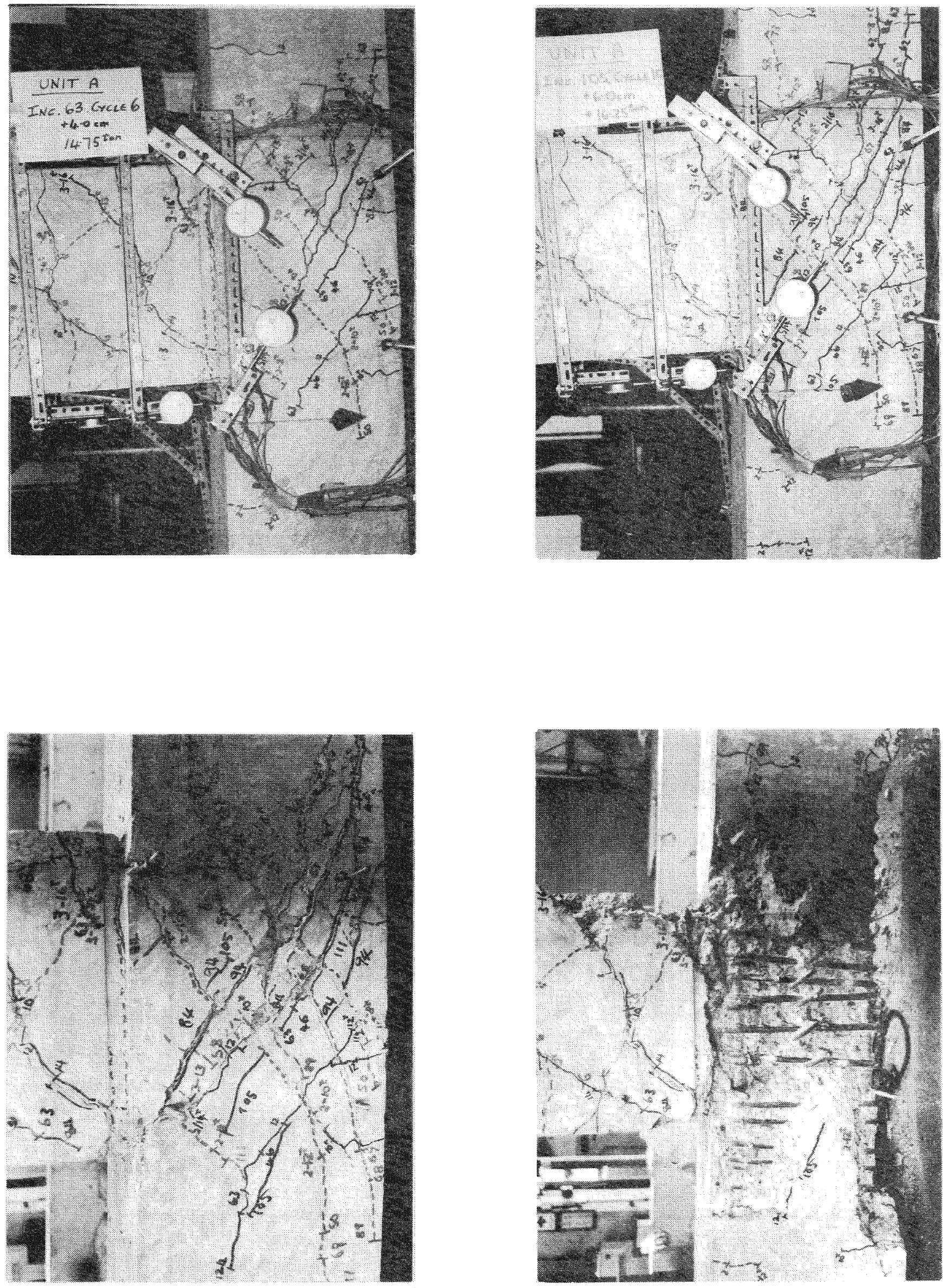

FIGURE 9: DEVELOPMENT OF CRACKING AND FAILURE OF UNIT A.

TOP, CYCLE 6, CYCLE 10, BOTTOM, CYCLE 13,

LOOSE CONCRETE REMOVED AFTER TEST. 


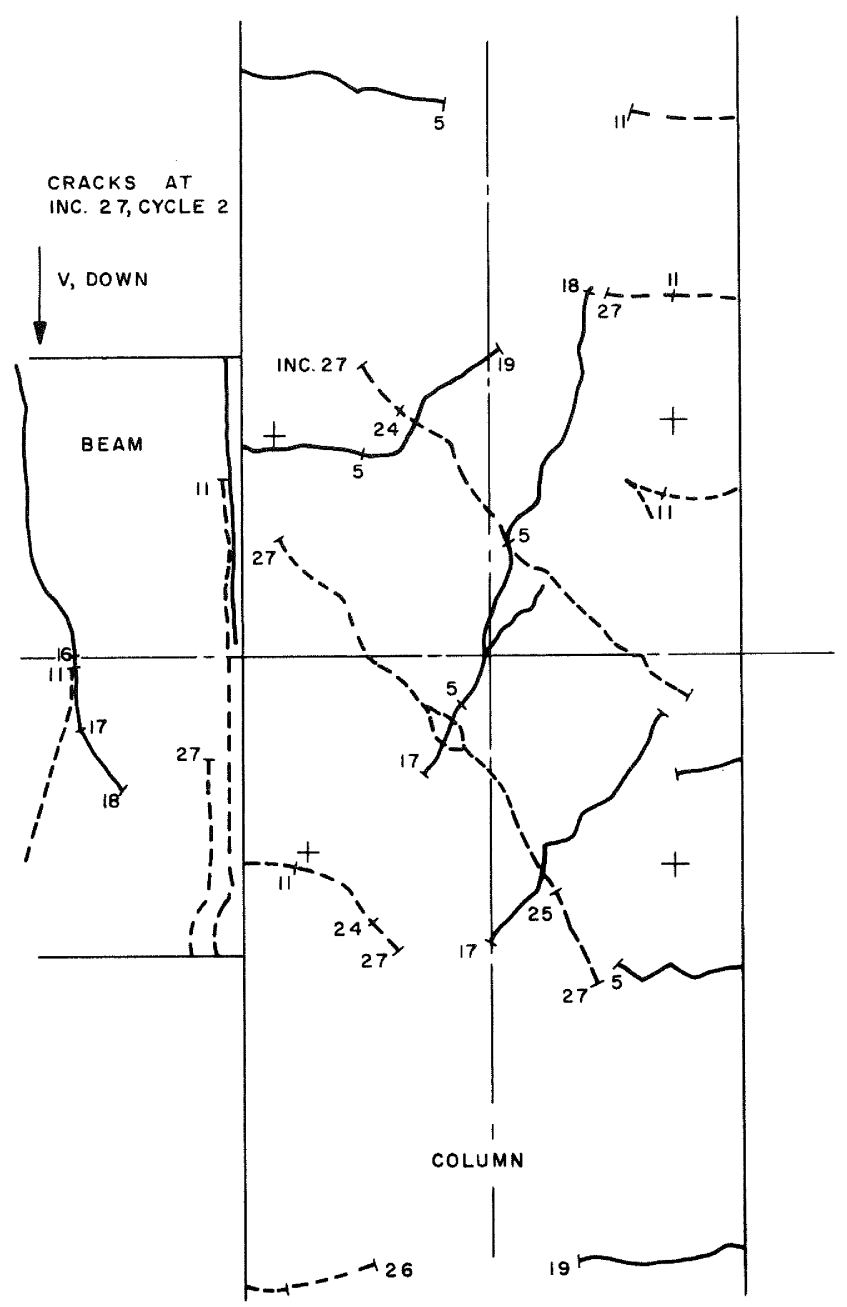

UNIT A

Fig. 10 CRACKS AT INC. 27, CYCLE 2

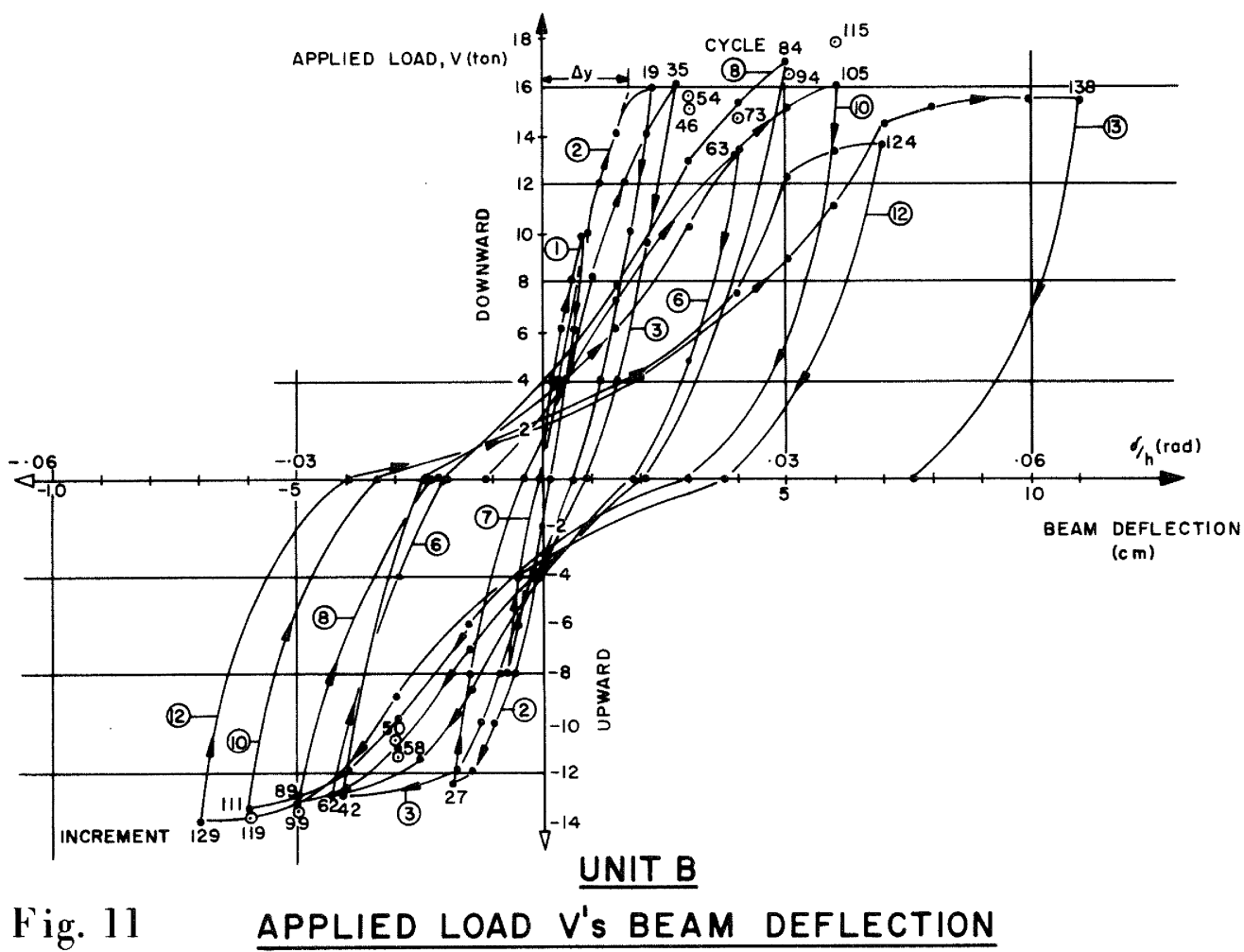




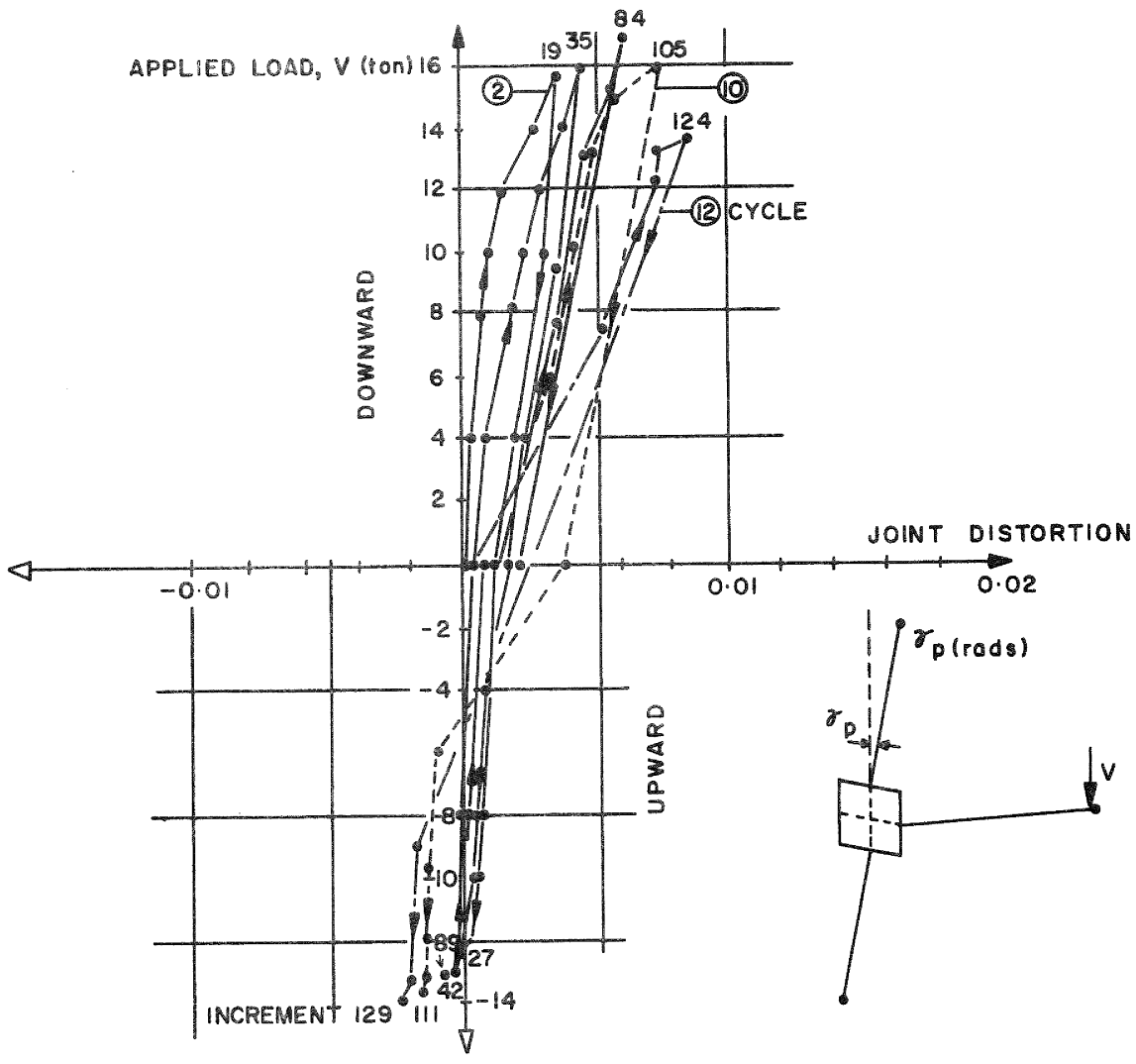

UNIT B

Fig. 12 APPLIED LOAD-JOINT DISTORTION

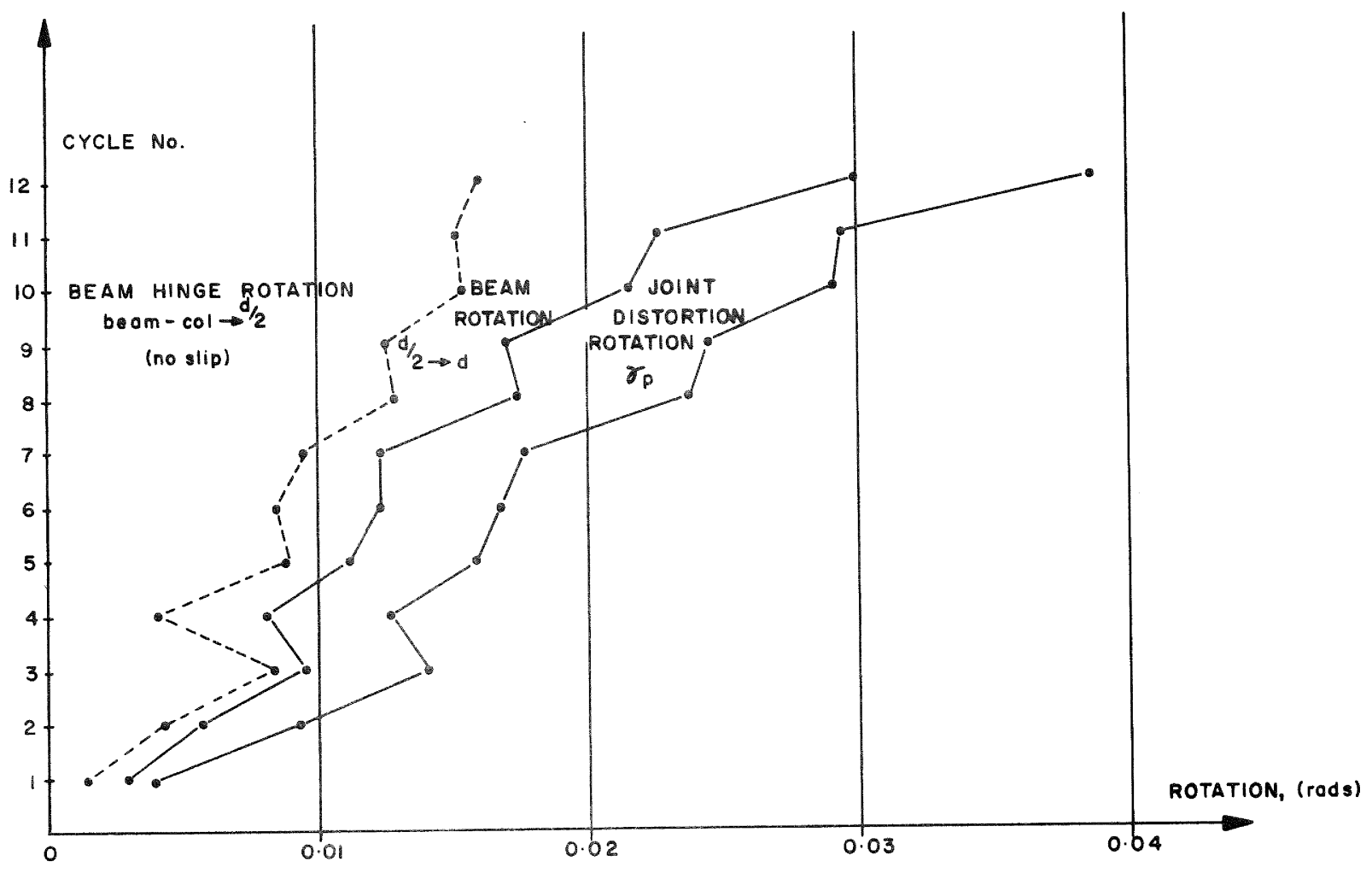

UNIT B

Fig. 13 


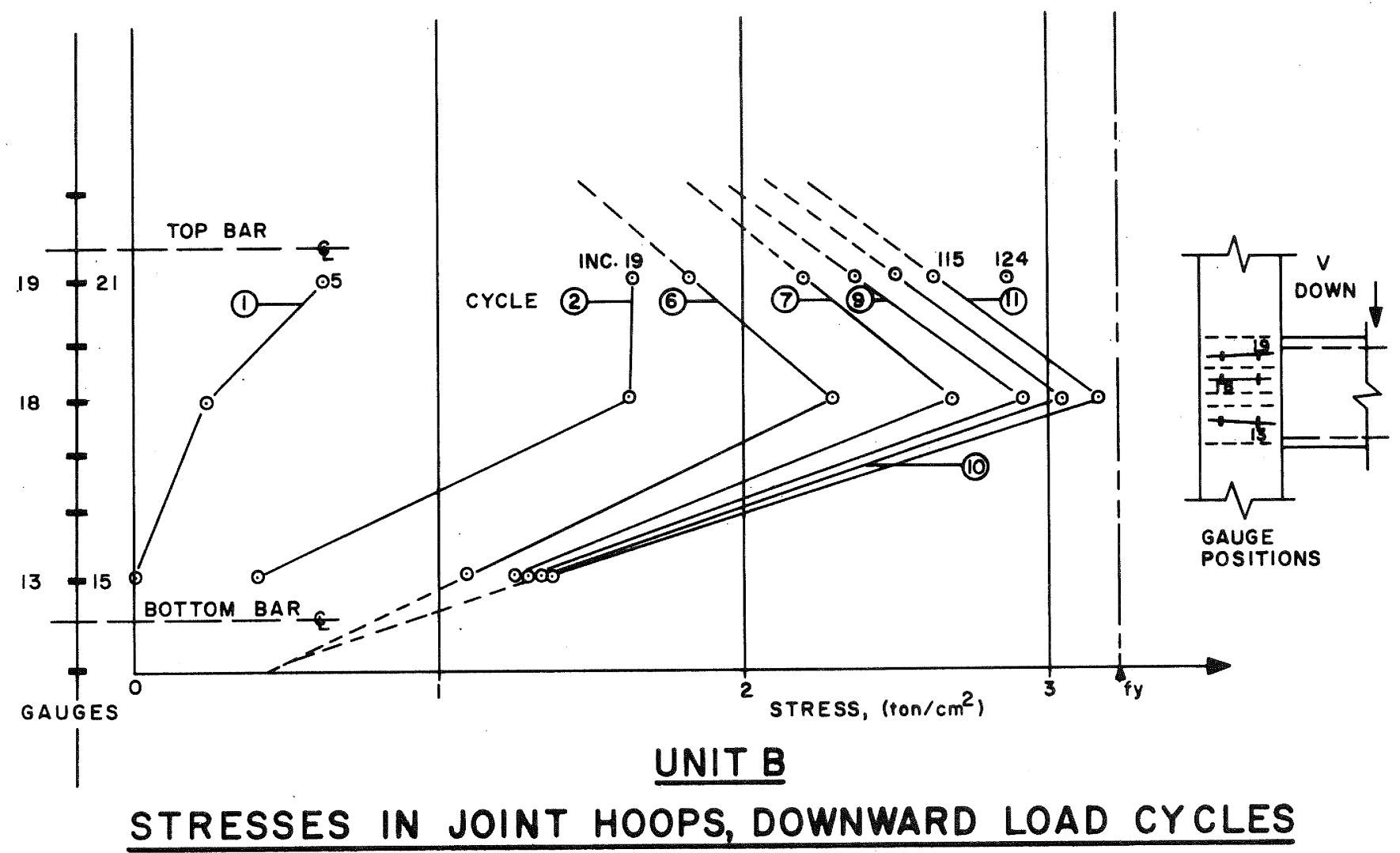

Fig. 14 

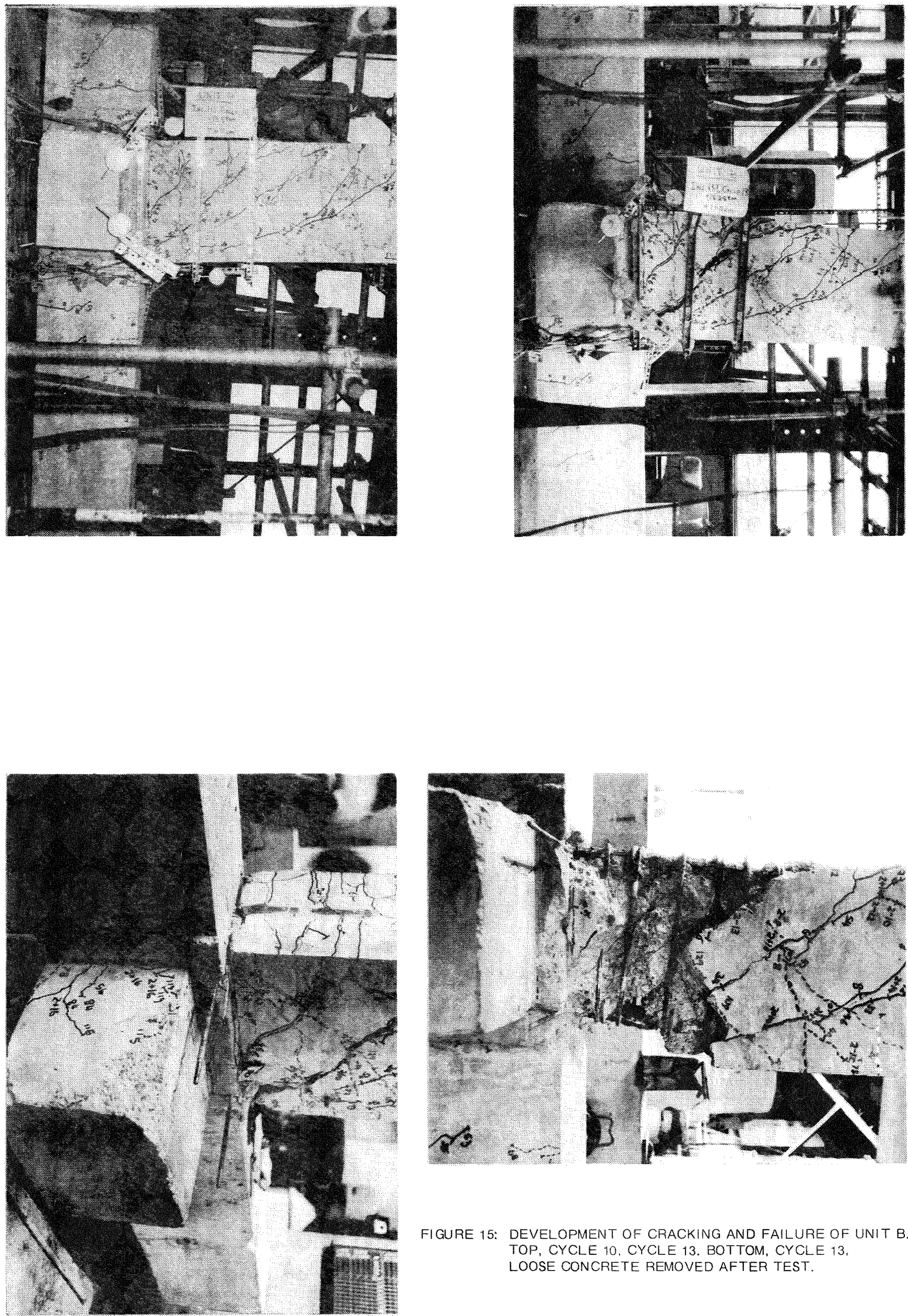

FIGURE 15: DEVELOPMENT OF CRACKING AND FAILURE OF UNIT B. TOP, CYCLE 10, CYCLE 13. BOTTOM, CYCLE 13, LOOSE CONCRETE REMOVED AFTER TEST. 

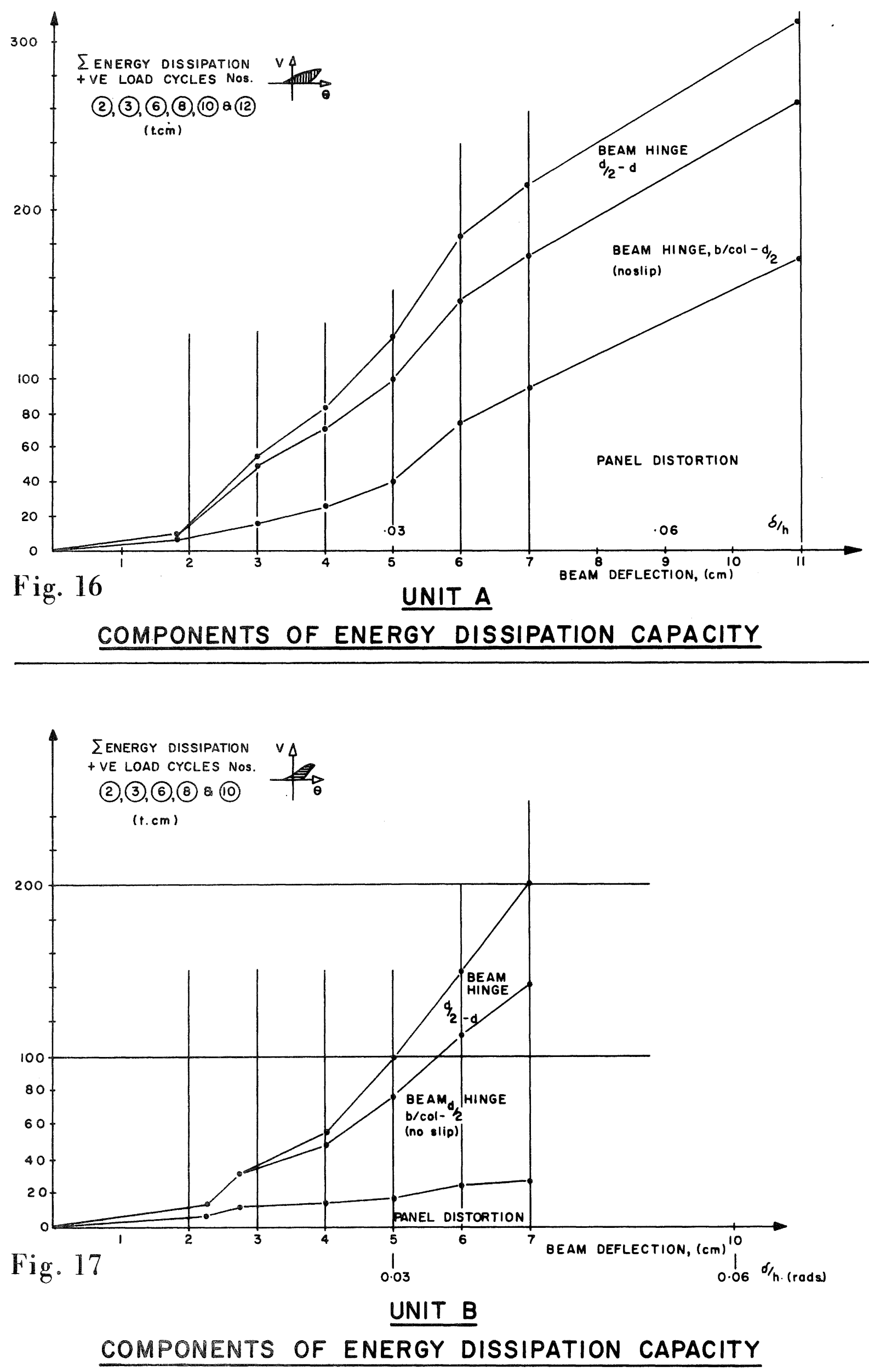


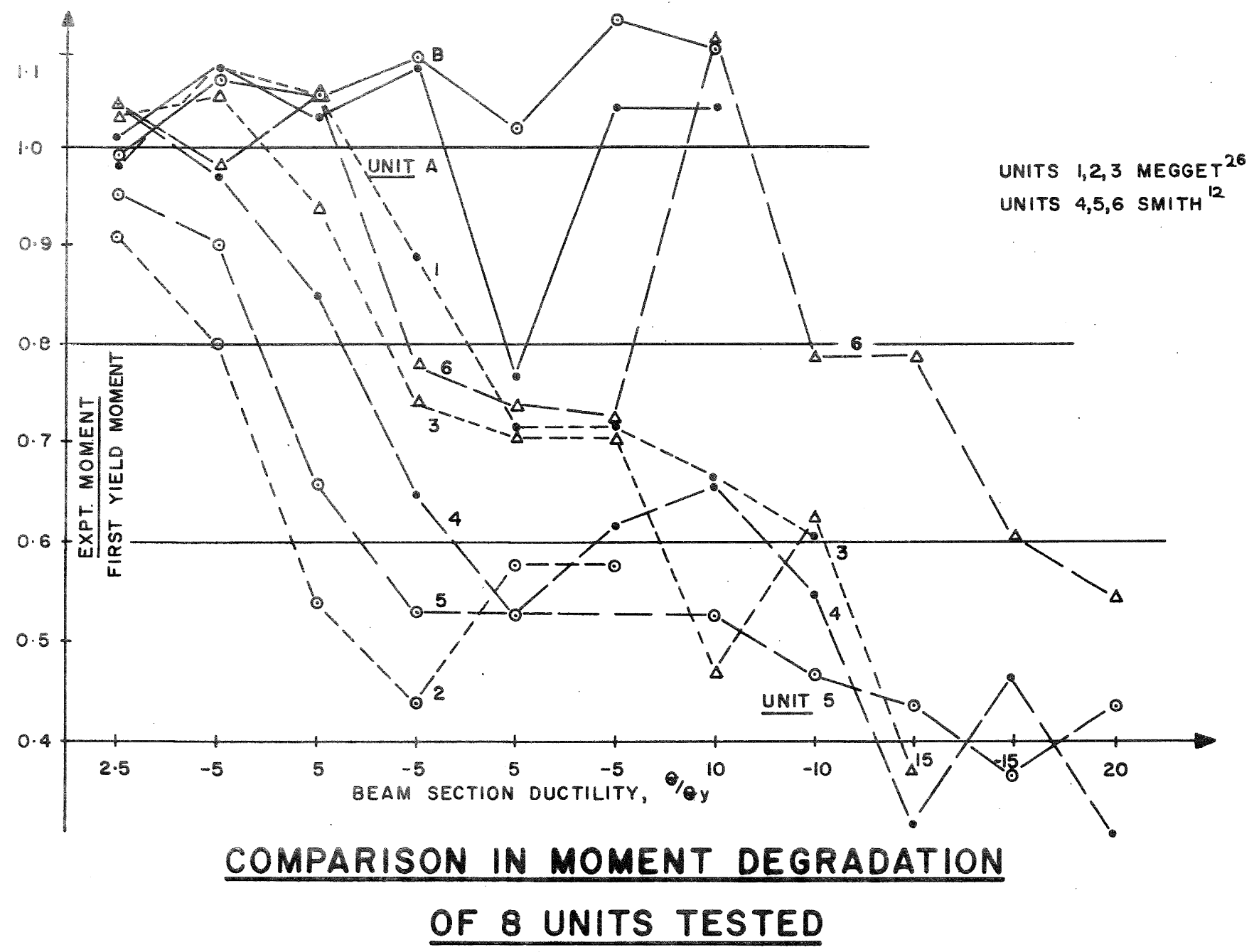

Fig. 18 